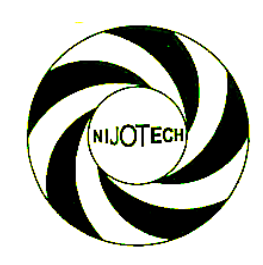

Nigerian Journal of Technology (NIJOTECH)

Vol. 37, No. 3, July 2018, pp. 600 - 604

Copyright@ Faculty of Engineering, University of Nigeria, Nsukka,

Print ISSN: 0331-8443, Electronic ISSN: 2467-8821 www.nijotech.com

http://dx.doi.org/10.4314/njt.v37i3.6

\title{
INVESTIGATION OF THE IMPACT OF PALM BUNCH ASH ON THE STABILIZATION OF POOR LATERITIC SOIL
}

\author{
A. W. Otunyo ${ }^{1, *}$ and C. C. Chukuigwe ${ }^{2}$

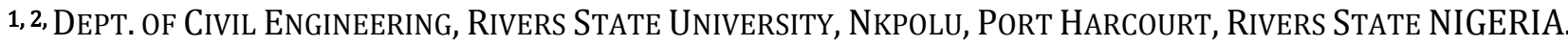 \\ E-mail addresses: 1 umutuigili@yahoo.com, ${ }^{2}$ chukuigwe@yahoo.com
}

\begin{abstract}
This study investigated the impact of palm bunch ash (PBA) on the stabilization of poor lateritic soil. The palm bunch ash in percentages by weight $(0 \%, 20 \%, 25 \%$ and $30 \%)$ was added to the lateritic soil. The $0 \%$ PBA acted as the control. The following parameters of the (lateritic soil+ palm bunch ash) were tested in the laboratory: Maximum Dry Density (MDD), Optimum Moisture Content (OMC), California Bearing Ratio (CBR) and unconfined compression strength (UCS). The values of the MDD, OMC, CBR and UCS increased as the PBA content in the lateritic soil was increased up to between 25\% PBA, thereafter the values started to decrease. The UCS of the (lateritic soil + palm bunch ash) specimen cured for 14 days were also found to higher than that of 28 days curing period at $20 \%$ PBA content. The UCS values for 14 days became higher than that at 28 days at $25 \%$ PBA content. The PBA can be used as a lateritic soil stabilizer between (20-25\%) PBA content.
\end{abstract}

Keywords: palm bunch ash, lateritic soil, California Bearing Ratio, Optimum Moisture Content, Maximum Dry Density.

\section{INTRODUCTION:}

Palm Bunch Ash (PBA) is one of the products of palm trees fruit bunch. Palm trees are economic trees dominantly grown in the south east and south-south of Nigeria where production averages approximately $95 \%$ of the total production in Nigeria [1]. The two major economical products from palm trees processing are palm wine and palm oil. Palm fruits are used for the production of palm oil and are harvested from the palm bunch. The empty palm bunches are the waste from the processing of the palm fruits. These wastes presently are used as organic fertilizers, bio-fuel in the rural areas, soap making (black soap) etc. The waste produce considerable amount of solids waste by-products in the form of fibres, shells and empty bunches which are discharged from the mills. Presently, shell and fibre are used extensively as bio fuel for the production of steam in the palm -oil mills as a means of waste disposal and energy recovery [2].

Load based structure of any type is as strong as its foundation. For that reason soil is a critical element influencing the success of a construction project. Soil is either part of the foundation or one of the raw materials used in the construction process [2].
Understanding the engineering properties of soil such as CBR and shear strength is crucial to obtaining strength and economic performance [3].

Lateritic soils range in performance from excellent to poor and in spite of considerable field and laboratory studies on these soils it is still not yet possible to accurately predict he behavior of all grades and generic groups of lateritic soils [4]. However, they are cheap. The cost of construction material is often exorbitant, particularly when most of the materials have to be imported [2]. Soil stabilization is a method often used to improve soil strength and increase resilience to softening by water through bonding the soil particles together with stabilizing agents [5].

Tropical climate possess an important consideration that must be factored into the design of low cost road. Research has shown that it is possible to provide construction material and method that are appropriate for that environment and are also affordable [6].

Stabilizers can be defined as the alteration of soils to enhance their physical properties. Stabilization includes compaction, pre-consolidation, drainage and many other such processes. Stabilization can increase the shear strength of soil and control the shrink swell 
properties of a soil, thus improving the load bearing capacity of foundation soil [7].

One may achieve stabilization by physically mixing the natural soil and materials together so as to achieve a homogeneous mixture or by stabilizing the material to an undisturbed soil deposit and obtaining interaction by letting it permeate through soil voids [8].

Soil stabilization additives are used to improve and maintain soil moisture content, increase soil particles cohesion and serve as cementing and water proofing agent [9]. The common soil stabilization techniques are becoming costly day by day due to the rise of cost of the stabilizing agents like cement, lime etc. [9]. Thus the use of agricultural wastes like rice husk ash, bamboo leaf ash, palm bunch ash and other agricultural waste materials will considerably reduce the cost of construction and as well as reducing the environmental hazards $[10,11]$.

The effect of Palm Bunch Ash on concrete properties by replacing Portland Lime Cement (PLC) by (5\%, 10\%, $15 \%, 20 \%$ and $25 \%$ ) of PBA was investigated [12]. It was concluded that compressive, flexural and split tensile strength of concrete with mix aggregate of 1:2:4 and water/cement ratio of 0.6 decrease as the PBA content was increased. At 15\% PBA content, the PBA starts to act as a retarding admixture. At 5\% PBA, the compressive, flexural and split tensile strength was not significantly reduced and a cost saving of $2.2 \%$ was achieved for every cubic meter of concrete.

Previous work carried out by [13] used PBA replacement levels of $(3 \%, 6 \%, 9 \%, 12 \%$ and $15 \%)$.

This study investigated the CBR and shear strength characteristics of a lateritic soil stabilized with (20\%, $25 \%$ and $30 \%$ ) PBA.

\section{MATERIALS AND METHOD}

\subsection{Materials}

\subsubsection{Palm Bunch Ash}

Dried palm bunch ash was obtained from a palm oil mill located at ALUU, a village near CHOBA, the location of the University of Port Harcourt, Nigeria. The palm bunch ash was sun dried for 5 weeks and then burnt to ashes at between $850-950^{\circ} \mathrm{C}$ at the Civil Engineering Laboratory of the Rivers State University, Nkpolu, Port Harcourt. The PBA was sieved using the 0.75 um sieve. The ash was found to be hygroscopic (absorbs atmospheric moisture) hence it was stored in air-tight container.

\subsubsection{Lateritic Soil}

The lateritic soil samples used for the Laboratory experiment was obtained from a construction site located in Port Harcourt. It was collected in a semisolid state and was reddish brown in colour.

\subsection{Method}

\subsubsection{Chemical Properties of PBA}

The PBA was tested in the Petro-Chemical Laboratory of the Rivers State University. Table 1 shows the chemical composition of the PBA.

Table 1: Chemical Properties of Palm Bunch Ash

\begin{tabular}{cc}
\hline Constituent & Percentage Weight in PBA (\%) \\
\hline $\mathrm{MgO}$ & 0.85 \\
$\mathrm{Fe}_{2} \mathrm{O}_{2}$ & 0.49 \\
$\mathrm{CaO}_{2}$ & 14.7 \\
$\mathrm{Al}_{2} \mathrm{O}_{3}$ & 15.38 \\
$\mathrm{SiO}_{2}$ & 60.85 \\
$\mathrm{TiO}_{2}$ & 0.01 \\
$\mathrm{Na}_{2} \mathrm{O}$ & 0.92 \\
$\mathrm{ZnO}$ & 1.00 \\
$\mathrm{CuO}$ & Trace \\
$\mathrm{CdO}$ & Trace \\
$\mathrm{MnO}$ & 0.88 \\
$\mathrm{PbO}$ & 0.14 \\
$\mathrm{LiO}$ & 6.4 \\
\hline
\end{tabular}

\subsubsection{Mix Proportion}

Mix proportioning by weight was used. PBA was added to the lateritic soil at $20 \%, 25 \%$ and $30 \%$ by weight.

\subsubsection{Particle Size Distribution.}

The sand and lateritic soil samples were graded for the determination of their particle size distributions. This was carried out in accordance with [14].

\subsubsection{Atterberg Limits.}

The liquid, limit, plastic limit and plasticity index of the lateritic soil were determined in accordance with [15].

\subsubsection{Compaction Tests}

PBA by weight of $(20,25$ and $30 \%)$ was added to the lateritic soil and thoroughly mixed together. Previous work on PBA as a stabilizing agent were carried out at between $3 \%$ to $15 \%$ PBA content. From the Compaction Test, the Optimum Moisture Content (OMC), Maximum Dry Density (MDD), California Bearing Ratio (CBR) and Unconfined Compression Strength of the lateritic soil samples mixed with the various percentages of PBA were determined in accordance with [16]. 


\section{RESULTS AND DISCUSSION}

\subsection{Atterberg Limits}

Table 2 shows the properties of the natural lateritic soil as obtained from the Civil Engineering Laboratory of the Rivers State University, Nkpolu Port Harcourt. From Table 2, the soil is classified under the AASHTO Classification system as A-2-6 subgroup. It is poorly graded. It is found to be medium plastic with a PI of 14.75 .

Table 2 Properties of the Natural Lateritic Soil

\begin{tabular}{ll}
\hline Properties & Quantity \\
\hline Percentage passing sieve No 200 & $25.40 \%$ \\
Liquid Limit (LL) \% & $36.00 \%$ \\
Plastic Limit (PL) \% & 21.25 \\
Plasticity Index PI (\%) & 14.75 \\
Optimum Moisture Content (OMC) \& & 17 \\
Maximum Dry Density (MDD) \% & 1.745 \\
California Bearing Ratio (CBR) \% & 14 \\
Unconfined Compressive Strength (KN/m2) & 107.7 \\
AASHTO Classification & A-2-6 \\
\hline
\end{tabular}

\subsection{Compaction Test.}

\subsubsection{OMC}

Figure 1 shows the graph of OMC versus the quantity of PBA in the lateritic soil. The OMC increased initially as the quantity of PBA increased. At 20\% PBA, the OMC starts to decrease until 25\% PBA when it starts again to increase as the quantity of PBA starts increasing. The PBA-soil mixture attained the optimum OMC of $20 \%$ at $20 \%$ PBA content. The initial increment was as a result of increasing demand for water by various cations and the clay mineral particles to undergo hydration reactions [17]. The subsequent decrease at $25 \%$ was due to cation exchange reaction that caused the flocculation of clay particles [18].

\subsubsection{MDD}

Figure 2 shows the graph of the MDD versus the quantity of the PBA. The MDD decreased as the PBA is increased between $0 \%$ to $20 \%$ PBA, thereafter the MDD starts to decrease again until at 25\% PBA when it starts to decrease with increasing PBA content. The increase in MDD up to 25\% PBA is due to the flocculation and agglomeration leading to volumetric decrease in density [1]. Above 25\% PBA content, there was a decrease in the MDD. The decrease is as a result of the void within the coarse aggregate being filled with PBA particles $[19,20]$. From Table 1 (chemical properties of PBA) it can be safely concluded that PBA is a pozzolana since it contains an appreciable amount of $\mathrm{SiO}_{2}$
(60.96\%). A pozzolana is a silicious material which in itself does not possess cementitious properties but will in finely divided form and in the presence of water react with calcium hydroxide $\mathrm{Ca}(\mathrm{OH})_{2}$. The PBA qualifies as a pozzolana since the percentage sum of its $\mathrm{SiO}_{2}, \mathrm{Al}_{2} \mathrm{O}_{3}$ and $\mathrm{Fe}_{2} \mathrm{O}_{2}$ components (76.9\%) exceeds the minimum requirement of $50 \%$ [21]. The $\mathrm{PBA}$ is the natural, very finely divided, highly reactive type of pozzolana. For pozzolanic reaction, it has to be combined with an optimum of 5\% lime [22]. These results compare favourably with the results obtained by [13].

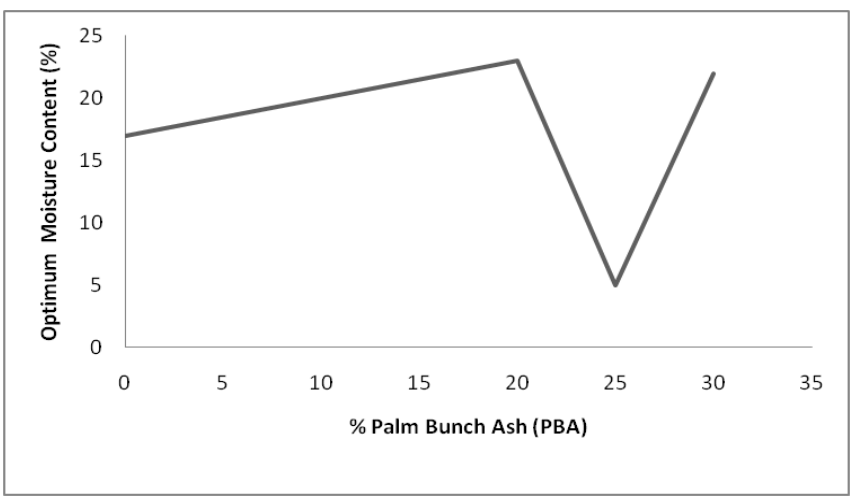

Figure 1: Optimum moisture content versus percentage PBA

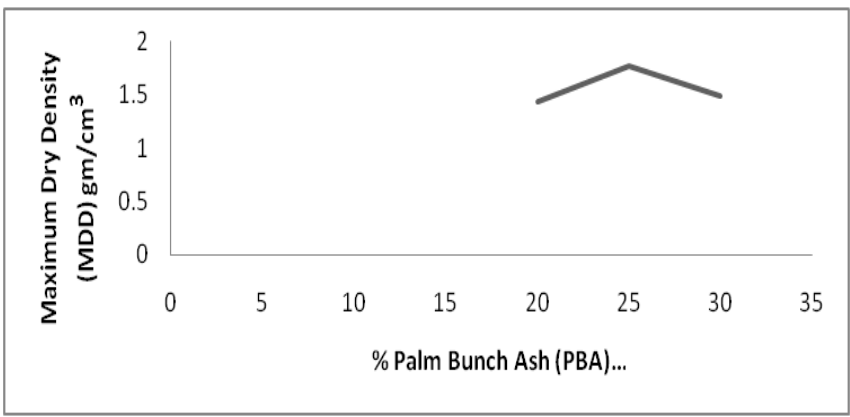

Figure 2: Maximum Dry Density versus percentage PBA

\subsubsection{CBR}

The graph of the CBR (soaked and unsoaked) of the lateritic soil mixed with PBA is shown in Figure 3. The CBR increases as the PBA content is increased up till 20\% PBA content, thereafter, the CBR starts to decrease as the PBA content is increased. The optimum CBR (soaked and unsoaked) occurred at 20\% PBA content in the lateritic soil. This result is similar to that obtained by [1] in which the optimum CBR occurred at $15 \%$ PBA content. This is attributed to the fact that PBA in its finely divided form in the presence of water reacts with $\mathrm{Ca}(\mathrm{OH})_{2}$ to form cementitious compounds [21]. It was observed that after stabilization with PBA, the CBR of the lateritic soil+PBA mixture increased from $3 \%$ to $8 \%$ and $32 \%$ respectively for the soaked and unsoaked samples. These values still did not satisfy 
the requirement of use as base and sub-base in road construction but the $32 \%$ unsoaked CBR at 20\% PBA satisfies the subgrade material condition for highway pavement construction[13].

\subsubsection{UCS}

Fig. 4 illustrates the effect of the PBA content on the UCS of the lateritic soil after 14 and 28 days respectively. At 14 and 28 days, the unconfined compressive strength increased as the PBA content was increasing. At 28 days and 20\% PBA the unconfined compressive strength stated to decrease up till $25 \%$ PBA when it started to increase again. At 14 days the maximum unconfined compressive strength was attained at 25\% PBA and after that the unconfined compressive strength started to decrease with increase in PBA content. The optimum UCS after 14 days was $200 \mathrm{~N} / \mathrm{mm} 2$ and occurred at $25 \%$ PBA content in the lateritic soil + PBA mixture, while the optimum, UCS after 28 days was $280 \mathrm{~N} / \mathrm{mm} 2$ and also occurred at $25 \%$ PBA content. The initial increment of UCS is due to the increase in MDD which has been explained to as resulting from flocculation and agglomeration leading to volumetric decrease in density [1].

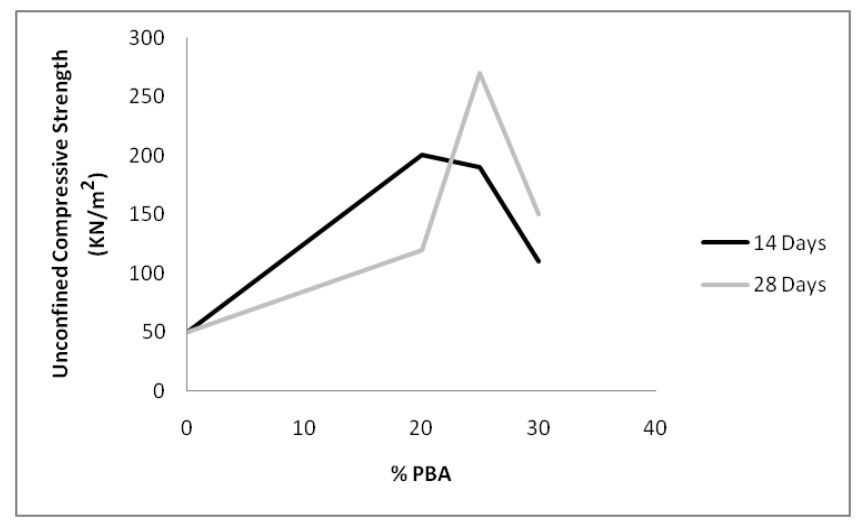

Figure 4: Unconfined Compressive Strength versus percentage $P B A$

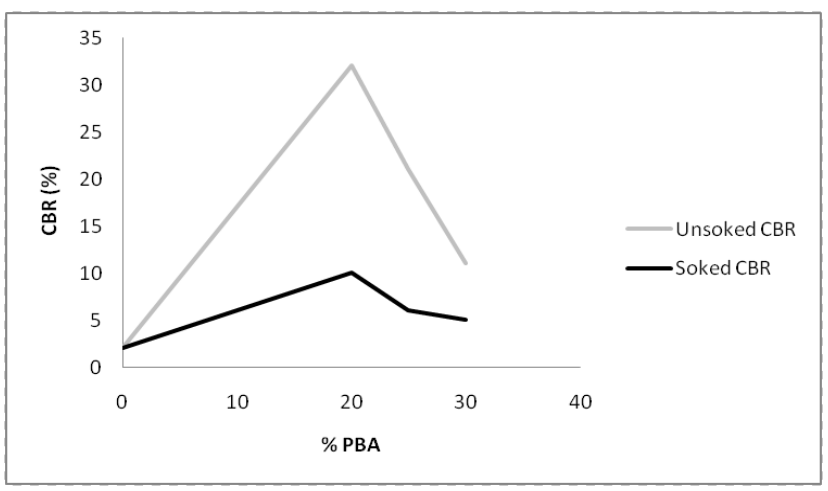

Figure 3: CBR against percentage PBA
A review of the results of the MDD, OMC CBR and UCS of the lateritic soil mixed with various percentages of PBA shows that their values improved as the PBA content was increased from $0 \%$ to between $(20-25 \%)$ PBA. It therefore follows that PBA can be used as a stabilizer at between (20-25\%) by weight.

\section{CONCLUSION}

From the results and discussion, the following conclusions were made.

1) The PBA is a pozzolan. It does not possess cementitious properties but will in finely divided form in the presence of water react with (lime) Ca $(\mathrm{OH})_{2}$ to form cementitious compounds.

2) The values of the MDD, OMC, CBR and UCS increased as the PBA content in the lateritic soil was increased up to between (20-25\%) PBA content, thereafter the values started to decrease.

3) The UCS of the (lateritic soil + palm bunch ash) specimen cured for 14 days were also found to higher than that of 28 days curing period (between 10\% - 20\%) PBA content. The UCS values for 14 days became higher than that at 28 days at $25 \%$ PBA content.

\section{RECOMMENDATION}

The PBA can be used as a lateritic soil stabilizer between (20-25\%) PBA content.

\section{ABBREVIATIONS}

CBR - California Bearing Ratio

MDD - Maximum Dry Density

OMC - Optimum Moisture Content

PLC - Portland Limestone Cement

PBA - Palm Bunch Ash

UCS - Unconfined Compression Strength

\section{REFERENCES}

[1] Ettu, L. O., Osadebe, N. and Mbajiorgu, M.S.W. Suitability of Nigeria agricultural by-products as cement replacement for concrete making. International Journal of Modern Engineering Research, Vol. 3, No. 2, pp. 1180-1185, 2013.

[2] Onyelowe, K. C. Effect of temperature changes on the Unconfined compressive strength of OPC stabilized engineering soil with palm bunch ash, PBA as admixture, Civil and Environmental Research, Vol. 8 No. 3, pp. 20-27, 2016.

[3] US Army Corps of Engineers. Unified Facilities Criteria. Geotechnical Engineering Procedures for foundation design of buildings and structures, 2005. 
[4] http://onlinepubs.trb/Onlinepubs/trr/ 1914/497/-610. Accessed 14th May 2018.

[5] Mukesh, A. P. and Patel, H. S., A review on effects of stabilizing agents for stabilization of weak soil, Civil and Environmental Research, Vol. 2, No. 6, pp. 1-7, 2012.

[6] Mbumbia, I. and Tiirloeqgi.. Performance characteristics of lateritic soil bricks fired at low temperatures: A case study of Cameroun. Construction and Building Materials, No. 14, pp. 121-131, 2002.

[7] Breneman, E. T,. Stabilization process, National Journal of Technology, Vol.12, pp. 18-22, 2009.

[8] Abood, T. T., Kasa, A. B. and Chik, Z. B.. Stabilization of silty clay soil using chloride compounds, JEST, Malaysia, Vol. 2, pp. 102-103, 2007.

[9] Salahudeen, A. B. and Akije, I. Stabilization of highway expansive soils with high loss of ignition content kiln dust, Nigerian Journal of Technology, Vol. 33, No. 2, pp. 141-148, 2014.

[10] Oyetola, E. P. and Abdullahi, M. The use of rice husk ash in low cost sandcrete block production, Leonardo Electronic Journal of Practices and Technology, Vol. 8, pp. 58-70, 2006.

[11] Sadeeq, J. A, Ochepo, J. and Salahudeen, A.B.. Assessment of bagaasse ash effect on the California bearing ratio of used oil contaminated lateritic soils, Nigerian Journal of Technology, Vol. 34, No. 2, pp. 223-231, 2015.

[12] Otunyo, A. W. and Alison, G. A. Investigation of the effect of palm bunch ash on concrete properties, Journal of Multidisciplinary Engineering Science Studies, Vol. 2 No. 11, pp. 1141-1146, 2016.

[13] Onyelowe, K. C, and Ubachukwu, A. O. Palm bunch ash stabilization of Olokoro-Umuahia lateritic soil using palm bunch ash as admixture, Umudike
Journal of Engineering Technology (UJET), Vol. 1, No. 2pp. 67-77, 2015.

[14] BS 812-103.2. -Testing aggregates. Methods for determination of particle size distribution. Sedimentation Tests, British Standards Institute, London, United Kingdom, 1989.

[15] BS 1377-2 -Methods of test for soils for civil engineering purposes. Classification tests. British Standards Institute, London, United Kingdom, 1990.

[16] BS 1377-4: Method of test for soils for civil engineering purposes. Compaction tests, British Standards Institute, London, United Kingdom, 1990.

[17] Osinubi, K. J. and Stephen, T. A. Influence of compactive efforts on bagasse ash treated black cotton soil. Nigerian Journal of Soil and Environmental Research, Vol. 7, pp. 92-101, 2007.

[18] Osinubi, K. J. Influence of compaction energy levels and delays on cement treated soil. Nigerian Society of Engineers Technical Transactions, Vol. 36, No. 4, pp. 1-13, 2000.

[19] Osinubi, K. J. Influence of compaction efforts and compaction delays on lime treated soils. Journal of Transportation Engineering. A.S.C.E., Vol. 124, No. 2, pp.149-155. 1998a.

[20] Osinubi, K. J. Permeability of lime treated lateritic soil. Journal of Transportation Engineering. A.S.C.E., Vol. 124, No. 5, pp.456-469. 1998b.

[21] Nnochiri, E. S. and Aderinlewo, 0. 0. Geotechnical properties of lateritic soil stabilized with banana leaves ash. FUOYE Journal of Engineering Technology, Vol. 1, No.1, pp. 116-119, 2016.

[22] Otoko, G. R., Fubara-Manuel, I., Chinweike, S. and Oyebode, O. J.. Soft soil stabilization using palm oil fibre ash. Journal of Multidisciplinary Engineering Science and Technology. Vol. 3, No.5, pp. 49544958, 2016. 